\title{
A Bayesian belief network model for community-based coastal resource management in the Kei Islands, Indonesia
}

\author{
Eriko Hoshino $^{1,2}$, Ingrid van Putten $^{1,3}$, Wardis Girsang ${ }^{4}$, Budy P. Resosudarmo $^{5}$ and Satoshi Yamazaki $^{2,3}$
}

\begin{abstract}
Understanding the specific relationships between ecological and socioeconomic conditions and marine tenure is likely to contribute to successful functioning of self-governance institutions for common-pool resources. Complex interrelationships of factors influencing fishing activities of coastal communities and implementation of customary marine tenure over their waters can be represented in a Bayesian belief network model. We developed a Bayesian belief network model that includes the links between factors for fishing communities in the Kei Islands in Indonesia, based on indepth local surveys. Our results showed that the cumulative impacts of multiple factors on key social, economic, and environmental outcomes can be much larger than the impact from a single source, which implies that management or policy intervention could be more effective when addressing multiple factors simultaneously. The local community's perception of fish stock abundance trends was the single most important factor influencing social, economic, and environmental outcomes of their community-based management system. The frequency of which outsiders were sighted in territorial waters was strongly (negatively) linked to weak or strong implementation of a customary tenure (Sasi) and the occurrence of intervillage and intravillage conflict. Ecological variables also drive these conflicts, which illustrates the close connection between ecological and social outcomes, and the importance of considering social-ecological systems as a whole.
\end{abstract}

Key Words: Bayesian belief network; community-based management; customary marine tenure; Indonesia; small-scale fisheries; socialecological systems

\section{INTRODUCTION}

Marine and coastal resources in many parts of the world have been managed traditionally by community-based governance systems that involve ownerships or property rights, commonly referred to as customary marine tenure (CMT). Customary marine tenure provides a vehicle by which state agencies and customary stakeholders may work in partnership to share authority of, and responsibility for, resource management, in what is termed cooperative management or comanagement (Cooke et al. 2000). Customary tenure regimes are the foundation of marine governance in much of the Pacific and have been documented throughout the world (Cinner 2005, Aswani et al. 2013). In response to degradation of many inshore marine resources, CMTs and traditional community-based resource management have attracted great attention as cost-effective, decentralized ways of managing coastal fisheries (Hviding 1998, Ruddle 1998). The viability of conservation strategies built on a foundation of marine tenure, however, remains ambiguous, as it is unclear whether marine tenure systems can withstand the profound economic development that much of the coastal states in the developing world are facing. A large body of literature has attempted to identify conditions that are important to successful functioning of self-governance institutions for common-pool resources (Cox et al. 2010, Pollnac et al. 2010). Studies specific to CMT have suggested that social and economic factors, such as poverty, dependency on resources, and human population size, affect the nature and functioning of marine tenure; however, specific relationships between socioeconomic conditions and marine tenure are still not well understood (Cinner 2005, Cinner et al. 2012b). There has been little discussion that specifically focuses on interdependencies between factors that affect marine resource management under a CMT arrangement.

In this article, we develop a Bayesian belief network (BBN) model that represents complex interrelationships of factors that influence small-scale fishing communities and implementation of customary management over their waters, and demonstrate the usefulness of the tool to identify the relative importance of factors to achieve social, economic, and environmental objectives. Bayesian belief networks are graphical models that represent a set of variables connected by directed, acyclic graphs which can be used to explore and display causal relationships between factors and assess the influences of each input variable on the output variables based on Bayesian principles. Bayesian belief networks have the ability to incorporate different types and sources of data, such as quantitative data, expert or local knowledge, and outputs from other models, and are capable of dealing with missing or incomplete data (Korb and Nicholson 2011). Such features make them well suited for small-scale fisheries where availability of quantitative data is often limited. A number of BBNs have been developed to aid natural resource management decisions, including fisheries (Varis and Kuikka 1997, Kuikka et al. 1999, Little et al. 2004, Haapasaari and Karjalainen 2010, Levontin et al. 2011, van Putten et al. 2013). The importance of integrating biological, economic, and sociological information into fisheries management plans was illustrated by Levontin et al. (2011), who highlighted the link between commitment and management success. Most of the existing applications of $\mathrm{BBNs}$ are in industrial-scale fisheries, with limited application in small-scale fisheries. One notable

${ }^{1}$ CSIRO Oceans and Atmosphere, Hobart, TAS, Australia, ${ }^{2}$ Tasmanian School of Business and Economics, University of Tasmania, Hobart, TAS, Australia, ${ }^{3}$ Centre for Marine Socioecology, University of Tasmania, Hobart, TAS, Australia, ${ }^{4}$ Faculty of Agriculture, University of Pattimura, Ambon, Indonesia, ${ }^{5}$ Indonesia Project, Arndt-Corden Department of Economics, Crawford School of Public Policy, Australian National University, ACT, Australia 
exception is van Putten et al. (2013), who applied a BBN to investigate the factors affecting the participation of indigenous fishers under key economic and socio-cultural drivers, such as presence or absence of a government employment program. To the best of our knowledge, BBN has not been applied to assess the factors affecting small-scale fisheries under a CMT or comanagement setting.

The Kei Islands, which are part of the Southeast Maluku Province in Indonesia, have well-established tenure systems where coastal resources have been communally owned and managed by Sasi, a set of traditional laws governing natural resources uses, including the spatial and temporal closure of fields, forests, reefs, and fishing grounds (Thorburn 2001). Our aim is to develop a BBN for the Kei Islands to gain understanding of the nature of interrelationships between various factors that influence smallscale fisheries, whose fishery resource is managed under a CMT regime (Sasi, in this case), and livelihoods of coastal communities; i.e., the social, economic, and environmental outcomes of their fishing activities. The model developed can provide a practical tool to guide resource managers and policy-makers to identify priorities and/or points of intervention for sustainable coastal resource management.

\section{METHODS}

\section{Study site}

Indonesia is the largest archipelago country in the world, with a population of approximately 250 million people. The study site is in the Kei Islands, a group of islands in the southeast part of Maluku in Indonesia (Fig. 1). In 2007, the Kei Islands separated into two districts: Kota Tual and Maluku Tenggara. The total population of the Kei Islands (Kota Tual and Maluku Tenggara districts combined) is approximately 162,000 (Badan Pusat Statistik 2014a, $b$ ).

Fig. 1. General location of the Kei Islands (main islands) and study sites at the subdistrict level. Source: Southeast Maluku Regional Development Planning Agency (2012).

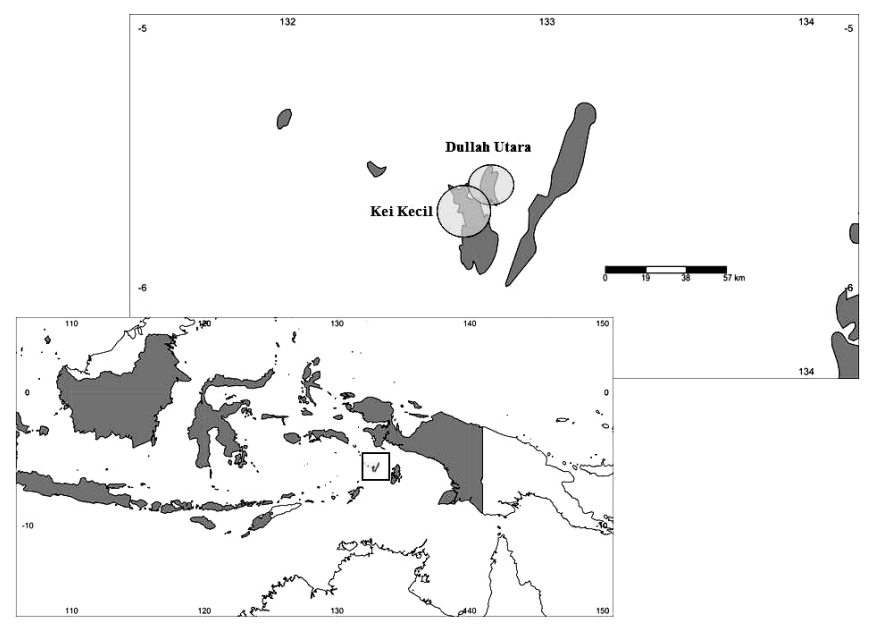

The people of the Kei Islands come from diverse ethnic and religious backgrounds. Kei's local economy is a mixture of subsistence agriculture and fishing, with copra (dried coconuts) and topshell (Trochus niloticus, called Lola by locals) exports providing cash income. Other marine-based small-scale industries, such as seaweed and pearl cultivation, also provide important livelihoods. The Kei Islands are known as the center of cultural and marine tourism in the Maluku Province, as Kei society maintains many cultural traditions, and tropical coral reefs are located around the islands. Fishing activities around the Kei Islands are mostly artisanal. The most common species caught in the area include small tuna (komu), coral cod (kerapu), mackerel (kawalinya), scad (momar), bluefin trevally (bubara), ornate emperor (sikuda), and anchovy (puri).

For a long time, daily activities of the people in Kei have been organized by a system of traditional rules that is called "Larwul Ngabal." One aspect of these traditional rules is Sasi. The goals of implementing Sasi in Kei are: (1) to manage harmony in social relationship, particularly between women and men; and (2) to manage natural resources and the environment. However, particularly since the 2000 decentralization era, there has been misinterpretation of Sasi by village leaders or certain communal groups driven by their own social, cultural, economic, and political motivation (based on the interviews in this study and in Adhuri 2013).

Rules for marine Sasi differ in the various villages in the Kei Islands. Some villages enact Sasi on the intertidal zone (meti), alternately closing portions of the coastal zone to allow reef organisms to replenish, while some villages in Kei close their entire meti for several weeks prior to the annual neap tide that occurs in September and October (Thorburn 2000). There are also examples of Sasi where certain areas are closed during spawning seasons for certain locally important fish species or to allow fry to attain optimal size before harvest (Nikijuluw 1994, Thorburn 2000). While some villages in other parts of Maluku use Sasi to restrict fishing gear types (Nikijuluw 1994), Sasi laut in the Kei Islands are generally area and/or species specific. In other words, the Sasi is applied to protect specific areas or certain valuable commodities, such as sea cucumber and topshell (Mosse et al. 2012). There are also some examples from villages in other parts of Maluku Province where Sasi laut is applied to small pelagic species (Nikijuluw 1994).

The heads of the villages typically lead the implementation of Sasi in their village, while the task of monitoring Sasi implementation relies on all village members. Breaking Sasi rules should be reported by village members to the head of their village. Those who break Sasi rule, or those who notice another person breaking the rules but who do not report the case, are punished by the head of village according to local customary rules. More examples of Sasi practices in the Kei Islands and Maluku Province are provides in Adhuri (2013), Novaczek et al. (2001), and Ruttan (1998).

\section{Survey}

Household and village leader surveys were conducted in four fishery villages in two subdistricts - Kei Kecil and Dullah Utara - between November and December 2013. Prior to the surveys, site visits were carried out by the research team members in order to identify main stakeholder groups in the region, as well as to develop and pretest the survey questionnaire in consultation with local experts in fisheries and Sasi. The experts included key personnel at the local technical/research institution (Tual State 
Fisheries Politechnic), researchers at the University of Pattimura in Ambon, and local government officers responsible for fisheries. A total of 296 randomly selected households were interviewed using a structured questionnaire. The interviews focused on individuals in a household who spent most of their time on fishing activities ("main fisher"). The selected villages were known to have a high concentration of fishers, and were located close to the coast. The questionnaire consisted of seven sections. The first three sections focused on the characteristics of the fishing operation, such as years of fishing operation, average catch per trip over the last 12 months, fishing gears used and ownership of the gears, number of paid employees on board, cost of fishing, and whether the fishers felt that the catch amount had changed during the last 12 months. The next two sections of the survey contained a series of questions about fisheries management, including customary management practices (Sasi laut). Examples of questions included the following: "Is there an area where fishing is temporarily prohibited as a practice of Sasi laut in your fishing area?", "In which months is fishing prohibited in your area?", "Which species are prohibited to be caught under the rules of Sasi laut?", and "Who needs to comply with the rules of Sasi laut?." The last two sections of the survey were comprised of questions concerning perceived states of their fishing grounds, including habitat condition or quality and current fish abundance trends, and questions regarding social structures, such as whether the respondent maintains a good relationship with other fishers, village or cultural leaders, and government fishery officers, and whether they are engaged in conflicts. Some demographic information was also collected in this section of the questionnaire.

The interviews were undertaken by local researchers from the University of Pattimura, all of whom attended training and information sessions. Demographic information for survey respondents, and fishing operation details (e.g., fishing gear used) for the sampled villages are summarized in Table 1. Most (67.8\%) survey respondents were small-scale operators with no more than four people on board per fishing trip (Table 1). There was a wide variability in the duration and timing of their fishing season. The duration of the most productive months for fishing was perceived to range from 3 months to 12 months. Most fishers went on daily fishing trips throughout the fishing season (average 6.2 days per week), but spent less than 3 days per week fishing during less productive seasons (Table 1). Fishers used a variety of fishing gears, including lift nets (bagan), fish aggregation devices (rumpon), small purse seine nets (pukat cincin), gill nets (jaring), hand lines (pancing), and fish traps (bubu). Self-reported catch per fishing trip (i.e., catch per unit effort [CPUE]) also varied widely, ranging from zero to more than 10 tonnes, due to different characteristics of species caught and type of gear used. The extremely large catch was typically attributed to larger operators who used lift nets or fish aggregation devices combined with purse seine nets, and where more than 15 employees were on board. However, a few small-scale operators ( $\leq$ four people) also reported large catches of pelagic species of more than 5 tonnes per trip. For reasons of confidentiality, it was not possible to disclose the names of the sampled villages or show their exact locations, but the locations of the study sites at the subdistrict level (Dullah Utara and Kei Kecil) are given in Fig. 1.
Table 1. Summary of demographics and fishing operations.

\begin{tabular}{|c|c|}
\hline \multicolumn{2}{|l|}{ Demographic } \\
\hline Age (years old) & $\begin{array}{l}\text { Between } 15 \text { and } 80 \text {; mean } 38.7 \text { years } \\
\text { old }\end{array}$ \\
\hline Gender & Male (294), female (2) \\
\hline $\begin{array}{l}\text { Formal school education } \\
\text { (years) }\end{array}$ & 0 to 17 ; mean 9 years \\
\hline Ethnic & $\begin{array}{l}\text { Bugis }(5 \%) \text {, Buton }(17.0 \%) \text {, Kei }(67 \%) \text {, } \\
\text { others }(11 \%)\end{array}$ \\
\hline Religion & Islam (91.3\%), Catholic (8.7\%) \\
\hline \multicolumn{2}{|l|}{ Fishing operations } \\
\hline Major fishing gear used & Bagan $(41.2 \%)$, rumpon $(7.8 \%)$ \\
\hline Types of boat used & $\begin{array}{l}\text { Traditional boat }(60.1 \%) \text {, long boat } \\
(16.6 \%) \text {, speed boat }(31.1 \%)\end{array}$ \\
\hline $\begin{array}{l}\text { Fishing seasons (most } \\
\text { productive months) }\end{array}$ & $\begin{array}{l}\text { Min } 3 \text { months (March-May) to } \max \\
12 \text { months }\end{array}$ \\
\hline $\begin{array}{l}\text { Number of paid employees } \\
\text { on board }\end{array}$ & $\begin{array}{l}\text { 1-4 people }(67.8 \%), 5-9 \text { people } \\
(16.6 \%), 10-14 \text { people }(3.0 \%),<15 \\
\text { people }(12.5 \%) \text {; mean } 5.3 \text { people }\end{array}$ \\
\hline $\begin{array}{l}\text { Average fishing days per } \\
\text { week }\end{array}$ & $\begin{array}{l}\text { Fishing season ( } 6.2 \text { days), nonfishing } \\
\text { season ( } 2.8 \text { days) }\end{array}$ \\
\hline $\begin{array}{l}\text { Average fishing hours per } \\
\text { trip }\end{array}$ & $\begin{array}{l}\text { Fishing season ( } 11.4 \text { hours), nonfishing } \\
\text { season ( } 5.7 \text { hours) }\end{array}$ \\
\hline $\begin{array}{l}\text { Mean and median catch per } \\
\text { fishing trip for coastal } \\
\text { nonpelagic species }\end{array}$ & $\begin{array}{l}\text { Mean }(138 \mathrm{~kg} / \text { trip}) \text {, median }(70 \mathrm{~kg} / \\
\text { trip) }\end{array}$ \\
\hline
\end{tabular}

\section{Bayesian belief network model}

The BBN modeling procedure consists of three steps: (1) identify the nodes representing system variables, such as those related to the environment (e.g., habitat quality and fish abundance trends), external stressors (e.g., presence of agriculture and population growth), and management systems (e.g., Sasi strength, and the presence of area/seasonal closures). Each variable can either be discrete or continuous and has a finite set of mutually exclusive states (e.g., high/low, present/absent); (2) create links representing causal relationships between these nodes (from parent node to child node; i.e., from cause to effect); and (3) generate probabilities attached to each node to quantify the relationships between connected links. The BBN we developed is based on multiple data sources, where key variables and causal links between different variables were identified through literature reviews, household and village leader surveys, and expert knowledge. Netica software was used to build the BBN and provide a sensitivity analysis by calculating the entropy and variance reduction scores to identify those parts of the model that most affect the output variables.

In the BBN, causal links represent the relationship between nodes using conditional probability tables (CPTs). For example, high fish abundance will increase the likelihood of catch per unit effort being high. These causal relationships influence the likelihood of outcome states of the variables of interest depicted in the BBN (Ticehurst et al. 2007). Conditional probabilities were generated mostly from the data obtained from the household surveys. Netica calculates CPTs based on Bayes theorem, whereby new information that becomes available revises the prior probability, which is then used to calculate the likelihood that the linked variables of interest are in particular states (referred to as posterior probability). It is not necessary to have questionnaires 
that explicitly ask cause and effects among selected variables, as Bayes theorem allows derivation of conditional probabilities from independent sets of events. For example, hypothetically, if $51 \%$ of a population is male, the probability of randomly selecting an adult for a survey and getting a male is given by $P(M)=0.51$. If it is also known that $9.5 \%$ of males own a boat, whereas only $1.7 \%$ of females own a boat, Bayes theorem indicates that the conditional probability that the respondent who is male given that the person owns a boat can be calculated as follows:

$$
P(M \mid B)=\frac{P(M) * P(B \mid M)}{[P(M) * P(B \mid M)]+[P(F) * P(B \mid F)]}
$$

where $P(F)$ is the probability of selecting female $(0.49$ in this example), $P(B \mid M)$ is the probability of getting someone who owns a boat, given that the person is a male $(0.095)$, and $P(B \mid F)$ is the probability of getting someone who owns a boat, given that the person is a female (0.017). After learning that the subject owns a boat, the probability is revised to be 0.853 .

When there was insufficient information on the probability distribution of events to populate CPTs from survey data, the CPTs in our research were either generated based on expert judgment (e.g., discussion with local scholars, fisheries managers, and village leaders), where feasible, or were given very simple scenarios (e.g., low/high) that were assigned equal probabilities (termed uninformative prior) when uncertainty was high. In the cases of expert judgment, a range of plausible alternative values was considered, and the resulting posterior probability distribution was also given a range (Table 2). For example, if sanctions are weak and no formal monitoring system is in place, the probability of having strong enforcement was considered to be very small, and probabilities of between $90 \%$ and $100 \%$ were assigned. Prior to construction of a full BBN model, a submodel was constructed for an initial exploration of important variables, in order to limit the number of variables included in the full model. A drawback of using BBNs is that a CPT grows exponentially with the number of parents nodes, which quickly makes a network intractable and uninformative.

One notable restriction of applying a standard BBN to socialecological systems is that it does not allow for feedback loops to be represented in the model due to the mathematical properties of the joint probability distribution. This limitation can be overcome by including dynamic variables that represent two or more points in time that indirectly account for feedback between the current states and the future (Yu et al. 2004). The variables related to fish stock abundance at two points in time ("Current abundance trend" and "Future fish abundance") were included to account for feedback effects of the current states to the future without creating a loop.

Three performance indicators representing economic, social, and environmental objectives of Sasi laut were considered: CPUE, conflicts, and future fish abundance, respectively. For each indicator, we considered scenarios where the values of major linked variables were changed to the extreme; for instance, changing the perception of habitat quality being damaged from $43.7 \%$ (base case) to $100 \%$ to see how these changes affected the indicator values. Since our main interest was on the influence on small-scale operators, the scenario analysis related to CPUE was examined for small-scale operators with up to four people on board (covering $67.8 \%$ of survey respondents). CPUE is generally much higher for pelagic species than for coastal species, and because our main interest was the small-scale operators and because Sasi is applied to nearshore coastal areas, the catch of the six most common pelagic species was excluded from CPUE. The excluded species were anchovies (puri), bigeye scad (kawalinya), small-tuna (koma), sardine (tembang), scad mackerel (momar), and Indian mackerel (lemma). A large proportion of these pelagic species is caught in water greater than $100 \mathrm{~m}$ in depth, although anchovies are caught mainly in relatively shallow water of about 10-15 m depth. Examples of coastal species included in CPUE are bluefin trevally (bubara), ornate emperor (sikuda), grouper or coral cod (kerapu), squid (cumi), snapper-like species (kakap merah, tenggiri, baronang), parrot fish (kakakutua), and small reef fishes, such as fusilier (lalosi).

A sensitivity analysis was carried out to evaluate the influence of each node on the social (conflict), economic (CPUE), and environmental (future fish abundance) indicators for each subdistrict. A sensitivity analysis allows the effective determination of how much a finding at one node in the BBN will likely change the probability outcome of another node (van Putten et al. 2013). Netica's measures for entropy reduction (for categorical variables) and variance reduction (for continuous variables) were applied as described in Marcot et al. (2006). The reduction scores were used to rank the factors from most to least important in terms of impacts on the node of interest. Larger variance reduction values indicate more influence. For example, fishing pressure (entropy reduction $=0.15$ ) has a far greater influence on the status of future fish abundance than the current perceived fish abundance trend (entropy reduction $=0.01$ ).

A common technique for validating $\mathrm{BBNs}$ is simply to ask the experts whether they agree with the model structure, discretization, and parameterization (Korb and Nicholson 2011). Another common validating test is to use sensitivity analysis (entropy/variance reduction scores). We used both sensitivity analyses and discussion with local scholars to explore alternative model structure. In order to test how sensitive the resulting posterior distributions of the key network variables were to the underlying assumptions made in the fixed (prior) distributions of the network, sensitivity tests were undertaken by altering the values of the priors between a low and high value. The resulting posterior probability was also given as a range in these cases. A workshop involving key stakeholder groups was organized in November 2015 to present our model results and obtain feedback to further improve/validate our model, although at the time of writing, such a meeting was still pending and it was not possible to include additional feedback in the results. The present model can benefit from inputs from additional stakeholder meetings.

\section{RESULTS}

The variable names selected in the full $\mathrm{BBN}$, and their base case states generated from the model, are shown in Table 2. The preliminary analysis using a submodel showed that most of the demographic factors (age, ethnic, religion, years of education), and some of the management-related variables (e.g., whether the rules of Sasi laut are written, who complies with Sasi laut) had little effect on the probability outcomes of the performance 
Table 2. Variables included in the final Bayesian belief network, definition, and base case states generated from the model.

\begin{tabular}{|c|c|}
\hline Variable names & Definition/Base case states (\% indicates posterior probability) \\
\hline \multicolumn{2}{|l|}{ Demographic } \\
\hline Subdistrict & Subdistrict where respondent resides: Kei Kecil (68.5\%), Dullah Utara (31.5\%) \\
\hline Alternative job & $\begin{array}{l}\text { Alternative job opportunity other than fishing available over the last } 12 \text { months for respondent: present } \\
(54.7 \%) \text {, absent }(45.3 \%)\end{array}$ \\
\hline \multicolumn{2}{|r|}{ (2) } \\
\hline Aquaculture & Not affected $(52.9 \%)$, affected little $(34.1 \%)$, highly affected $(12.9 \%)$ \\
\hline Deforestation & Not affected $(60.7 \%)$, affected little $(31.1 \%)$, highly affected $(8.2 \%)$ \\
\hline Population growth & Not affected $(49.7 \%)$, affected little $(46.0 \%)$, highly affected $(4.3 \%)$ \\
\hline Tourism & Not affected $(81.8 \%)$, affected little $(16.2 \%)$, highly affected $(2.0 \%)$ \\
\hline Urbanization & Not affected $(66.1 \%)$, affected little $(29.1 \%)$, highly affected $(4.8 \%)$ \\
\hline \multicolumn{2}{|l|}{ Environment } \\
\hline Habitat quality & $\begin{array}{l}\text { Perceived habitat quality of the respondent's fishing grounds: improved ( } 22.6 \%) \text {, unchanged }(35.8 \%) \text {, } \\
\text { damaged }(41.6 \%)\end{array}$ \\
\hline Current abundance trend & $\begin{array}{l}\text { Perceived current fish abundance trend at respondents' fishing grounds: up }(23.0 \%) \text {, unchanged }(27.2 \%) \text {, } \\
\text { down }(49.9 \%)\end{array}$ \\
\hline Future fish abundance $\dagger$ & Low $(48.5-62.7 \%)$, high $(37.3-51.5 \%)$ \\
\hline \multicolumn{2}{|l|}{ Fishing } \\
\hline Catch per unit effort (CPUE) coastal & $\begin{array}{l}\text { Average catch }(\mathrm{kg}) \text { per trip excluding pelagic species over the last } 12 \text { months: low }(0-99 \mathrm{~kg}, 47.5 \%) \text {, } \\
\text { medium }(100-200 \mathrm{~kg}, 26.2 \%) \text {, high }(200 \mathrm{~kg}, 26.3 \%)\end{array}$ \\
\hline Catch trend & Perceived catch trend at respondents' fishing grounds: up (19.6\%), unchanged $(36.6 \%)$, down $(43.8 \%)$ \\
\hline Num of paid employee & Number of paid employee on board: $0-4(67.3 \%), 5-9(16.7 \%), 10-14(3.3 \%),>15(12.7 \%)$ \\
\hline Fishing gear & $\begin{array}{l}\text { Whether the respondents have modernized their fishing gear over the last } 12 \text { months: modernized } \\
(32.6 \%) \text {, unchanged }(67.4 \%)\end{array}$ \\
\hline$\%$ Gear own & Percentage of fishing gear owned by the respondents: $0-33(39.4 \%), 34-65(19.4 \%), 66-100(40.8 \%)$ \\
\hline Cost & Cost of fishing per trip (Rp000 per trip): low (<Rp500k, 77.1\%), medium to high ( $>$ Rp500k, 22.9\%) \\
\hline Fishing pressure $\dagger$ & Low $(47.7-53.1 \%)$, High $(46.9-52.3 \%)$ \\
\hline \multicolumn{2}{|l|}{$\begin{array}{l}\text { Customary marine tenure (CMT) (Sasi } \\
\text { laut) }\end{array}$} \\
\hline Sasi strength & $\begin{array}{l}\text { Whether the respondents perceive that the strength of Sasi has changed over time: weakened/disappeared } \\
(92.8 \%) \text {, unchanged }(3.0 \%) \text {, strengthened }(4.3 \%)\end{array}$ \\
\hline Area closure & Sea area closure in the village's territorial waters: present $(86.3 \%)$, absent $(13.7 \%)$ \\
\hline$\%$ seasonal closure & Percentage of year closed by Sasi laut: $0-9(90.4 \%), 10-49(1.3 \%), 50-100(8.3 \%)$ \\
\hline Num of species protected & $\begin{array}{l}\text { Number of species protected by Sasi laut, such as Lola, Tripang (sea cucumber), and Lainnya: } 0-1 \\
\text { species }(0.7 \%), 1-2 \text { species }(64.1 \%), 2-3 \text { species }(35.2 \%)\end{array}$ \\
\hline Fine_money & Presence of fine in terms of money when an offense is found: yes $(6.4 \%)$, no $(93.6 \%)$ \\
\hline Fine_goods & Presence of fine in terms of goods when an offense is found: yes $(1.5 \%)$, no $(98.5 \%)$ \\
\hline Suspension & Whether the offender will be suspended from fishing activities: yes $(6.4 \%)$, no $(93.6 \%)$ \\
\hline Exclusion & Whether the offender will be excluded from the village: yes $(1.0 \%)$, no $(99.0 \%)$ \\
\hline Enforcement $\dagger$ & $\begin{array}{l}\text { Strength of enforcement (combined effect of monitoring and sanction): weak (84.7-96.4\%), strong (3.6- } \\
15.3 \%)\end{array}$ \\
\hline Sanction $\dagger$ & $\begin{array}{l}\text { Strength of sanction, based on the presence of fine, suspension, and exclusion above: weak }(89.3-91.3 \%) \text {, } \\
\text { strong }(9.7-10.7 \%)\end{array}$ \\
\hline Sasi implementation $\dagger$ & $\begin{array}{l}\text { Combined effects of area closure, seasonal closure, and species protection: weak (58.5-74.6\%), strong } \\
(25.4-41.5 \%)\end{array}$ \\
\hline Monitoring $\dagger$ & Monitoring of infringement: yes $(50 \%)$, no $(50 \%)$ \\
\hline \multicolumn{2}{|r|}{ (V) } \\
\hline Intervillage conflict & Presence of intervillage conflict: present (30.6\%), absent (69.4\%) \\
\hline Intravillage conflict & Presence of intravillage conflict: present (30.1\%), absent $(69.9 \%)$ \\
\hline Village leader relation & Relationship with a village leader: good $(98.3 \%)$, not good $(1.7 \%)$ \\
\hline Fishery officer relation & Relationship with fishery officers: good $(64.5 \%)$, not good $(35.5 \%)$ \\
\hline Outsiders & Sighting of outsiders fishing in their sea territory: present $(47.2 \%)$, absent $(52.8 \%)$ \\
\hline
\end{tabular}

indicators and their entropy/variance reduction scores. As a result, they were excluded from the full model. The final BBN contained 34 nodes and 55 links, which generated 2827 conditional probabilities. The scenarios that tested the influence of changes in key variables on the performance indicators values are given in Table 3 . The percentages indicate posterior probability distributions conditional on the linkages of variables included in the BBN (Fig. 2).
CPUE is an important indicator of economic productivity, as high CPUE suggests more fish are caught given the same amount of input. CPUE for coastal species ranges widely from zero to $920 \mathrm{~kg} /$ trip, with median $70 \mathrm{~kg} /$ trip and mean $138 \mathrm{~kg} /$ trip. Low CPUE in this study refers to catch less than $100 \mathrm{~kg} /$ trip based on the mean value as well as examples from similar tropical reef fisheries in southeast Asia (Viswanathan et al. 2001, Liese et al. 2007). The base case results suggest that the probability of a low 
Table 3. Scenarios considered and resulting posterior probability distribution (\%) of economic, social, and environmental performance indicators.

\begin{tabular}{|c|c|c|c|c|}
\hline Scenarios & $\begin{array}{l}\text { Economic } \\
\text { Catch per unit effort } \\
\text { (CPUE) }\end{array}$ & $\begin{array}{l}\text { Social } \\
\text { (Intravillage conflict) }\end{array}$ & $\begin{array}{l}\text { Social } \\
\text { (Intervillage conflict) }\end{array}$ & $\begin{array}{l}\text { Environmental } \\
\text { (Future fish stock abundance) }\end{array}$ \\
\hline Base case & $\begin{array}{l}\text { Low }(52.1 \%) ; \text { med } \\
(25.3 \%) ; \text { high }(22.5 \%)\end{array}$ & $\begin{array}{l}\text { Absent }(69.4 \%) \text {; present } \\
(30.6 \%)\end{array}$ & $\begin{array}{l}\text { Absent }(69.9 \%) \text {; present } \\
(30.1 \%)\end{array}$ & $\begin{array}{l}\text { Low }(48.5-62.7 \%) \text {; high }(37.3- \\
51.5 \%)\end{array}$ \\
\hline 1) Habitat quality improved & $\begin{array}{l}\text { Low }(41.7 \%) ; \text { med } \\
(29.3 \%) ; \text { high }(28.9 \%)\end{array}$ & $\begin{array}{l}\text { Absent }(69.0 \%) \text {; present } \\
(31.0 \%)\end{array}$ & $\begin{array}{l}\text { Absent }(70.5 \%) ; \text { present } \\
(29.5 \%)\end{array}$ & $\begin{array}{l}\text { Low }(23.5-47.2 \%) \text {; high }(52.8- \\
76.5 \%)\end{array}$ \\
\hline $\begin{array}{l}\text { 2) Abundance trend down or } \\
\text { up }\end{array}$ & $\begin{array}{l}\text { Down: low }(42.3 \%) ; \text { med } \\
(30.7 \%) ; \operatorname{high}(22.6 \%)\end{array}$ & $\begin{array}{l}\text { Down: absent }(74.1 \%) \text {, } \\
\text { present }(25.9 \%) \text {; Up: } \\
\text { absent }(72.3 \%) \text {; present } \\
(27.3 \%)\end{array}$ & $\begin{array}{l}\text { Down: absent }(67.0 \%) \text {, } \\
\text { present }(33.0 \%) \text {; UP: } \\
\text { absent }(59.6 \%) \text {; present } \\
(40.4 \%)\end{array}$ & $\begin{array}{l}\text { Down: low }(33.7-49.3 \%) \text {; high } \\
(50.7-66.3 \%)\end{array}$ \\
\hline 3) Sighting of outsiders absent & $\begin{array}{l}\text { Low }(49.2 \%) ; \text { med } \\
(28.3 \%) ; \text { high }(22.5 \%)\end{array}$ & $\begin{array}{l}\text { Absent }(66.6 \%) \text {; present } \\
(33.4 \%)\end{array}$ & $\begin{array}{l}\text { Absent }(73.6 \%) ; \text { present } \\
(26.4 \%)\end{array}$ & $\begin{array}{l}\text { Low }(47.2-62.7 \%) \text {; high }(37.3- \\
52.8 \%)\end{array}$ \\
\hline 4) 1) + 2) & $\begin{array}{l}\text { Low }(41.2 \%) ; \text { med } \\
(29.3 \%) ; \text { high }(29.4 \%)\end{array}$ & $\begin{array}{l}\text { Absent }(73.3 \%) \text {; present } \\
(26.7 \%)\end{array}$ & $\begin{array}{l}\text { Absent }(59.8 \%) \text {; present } \\
(40.2 \%)\end{array}$ & $\begin{array}{l}\text { Low }(13.2-32.0 \%) \text {; high }(68.0- \\
86.8 \%)\end{array}$ \\
\hline 5) 1$)+2)+3)$ & $\begin{array}{l}\text { Low }(28.3 \%) ; \text { med } \\
(31.4 \%) ; \text { high }(40.3 \%)\end{array}$ & $\begin{array}{l}\text { Absent }(75.8 \%) \text {; present } \\
(24.2 \%)\end{array}$ & $\begin{array}{l}\text { Absent }(65.7 \%) ; \text { present } \\
(34.3 \%)\end{array}$ & $\begin{array}{l}\text { Low }(13.2-31.9 \%) \text {; high }(68.1- \\
86.8 \%)\end{array}$ \\
\hline 6) Catch trend down & $\begin{array}{l}\text { Low }(51.9 \%) ; \text { med } \\
(25.7 \%) ; \text { high }(22.3 \%)\end{array}$ & $\begin{array}{l}\text { Absent }(73.7 \%) \text {; present } \\
(26.3 \%)\end{array}$ & $\begin{array}{l}\text { Absent }(59.7 \%) \text {; present } \\
(40.3 \%)\end{array}$ & $\begin{array}{l}\text { Low }(47.4-62.9 \%) \text {; high }(37.1- \\
52.6 \%)\end{array}$ \\
\hline $\begin{array}{l}\text { 7) Abundance trend down }+ \\
\text { catch trend down }\end{array}$ & $\begin{array}{l}\text { Low }(53.8 \%) ; \text { med } \\
(25.5 \%) ; \text { high }(20.7 \%)\end{array}$ & $\begin{array}{l}\text { Absent }(83.6 \%) \text {; present } \\
(16.4 \%)\end{array}$ & $\begin{array}{l}\text { Absent }(57.3 \%) \text {; present } \\
(42.3 \%)\end{array}$ & $\begin{array}{l}\text { Low }(50.7-70.6 \%) ; \text { high }(29.4 \\
49.3 \%)\end{array}$ \\
\hline 8) Sasi strengthened & $\begin{array}{l}\text { Low }(34.3 \%) ; \text { med } \\
(34.1 \%) ; \text { high }(31.5 \%)\end{array}$ & $\begin{array}{l}\text { Absent }(70.0 \%) \text {; present } \\
(30.0 \%)\end{array}$ & $\begin{array}{l}\text { Absent }(69.6 \%) ; \text { present } \\
(30.4 \%)\end{array}$ & $\begin{array}{l}\text { Low }(48.2-62.1 \%) \text {; high }(37.9 \\
51.8 \%)\end{array}$ \\
\hline $\begin{array}{l}\text { 9) Modernization of fishing } \\
\text { gear }\end{array}$ & $\begin{array}{l}\text { Low }(46.9 \%) ; \text { med } \\
(26.5 \%) ; \text { high }(26.6 \%)\end{array}$ & $\begin{array}{l}\text { Absent }(70.0 \%) \text {; present } \\
(30.0 \%)\end{array}$ & $\begin{array}{l}\text { Absent }(69.5 \%) \text {; present } \\
(30.5 \%)\end{array}$ & $\begin{array}{l}\text { Low }(48.9-63.2 \%) \text {; high }(36.8- \\
51.1 \%)\end{array}$ \\
\hline $\begin{array}{l}\text { 10) Bad relationship with } \\
\text { village leader }\end{array}$ & Not applicable & $\begin{array}{l}\text { Absent }(49.7 \%) \text {; present } \\
(50.3 \%)\end{array}$ & $\begin{array}{l}\text { Absent }(69.9 \%) ; \text { present } \\
(30.1 \%)\end{array}$ & Not applicable \\
\hline $\begin{array}{l}\text { 11) Bad relationship with } \\
\text { fishery officer }\end{array}$ & Not applicable & $\begin{array}{l}\text { Absent }(64.7 \%) \text {; present } \\
(35.3 \%)\end{array}$ & $\begin{array}{l}\text { Absent }(69.9 \%) ; \text { present } \\
(30.1 \%)\end{array}$ & Not applicable \\
\hline 12) Tourism highly affected & Not applicable & $\begin{array}{l}\text { Absent }(49.8 \%) \text {; present } \\
(50.2 \%)\end{array}$ & $\begin{array}{l}\text { Absent }(70.0 \%) \text {; present } \\
(30.0 \%)\end{array}$ & Not applicable \\
\hline 13) Strong enforcement & Not applicable & Not applicable & Not applicable & $\begin{array}{l}\text { Low }(44.1-60.4 \%) \text {; high }(39.6- \\
55.9 \%)\end{array}$ \\
\hline 14) Strong Sasi implementation & Not applicable & Not applicable & Not applicable & $\begin{array}{l}\text { Low }(38.7-57.4 \%) \text {; high (42.6- } \\
61.3 \%)\end{array}$ \\
\hline $\begin{array}{l}\text { 15) Population growth not } \\
\text { affected }\end{array}$ & $\begin{array}{l}\text { Low }(51.8 \%) ; \text { med } \\
(25.5 \%) ; \text { high }(22.7 \%)\end{array}$ & $\begin{array}{l}\text { Absent }(71.0 \%) \text {; present } \\
(29.0 \%)\end{array}$ & $\begin{array}{l}\text { Absent }(69.6 \%) ; \text { present } \\
(30.4 \%)\end{array}$ & $\begin{array}{l}\text { Low }(42.8-59.8 \%) \text {; high }(40.2- \\
57.2 \%)\end{array}$ \\
\hline 16) Alternative job present & Not applicable & Not applicable & Not applicable & $\begin{array}{l}\text { Low }(38.8-57.7 \%) \text {; high }(42.3- \\
61.2 \%)\end{array}$ \\
\hline 17) 13$)+14)+15)+16)$ & $\begin{array}{l}\text { Low }(51.7 \%) ; \text { med } \\
(25.8 \%) ; \text { high }(22.5 \%)\end{array}$ & $\begin{array}{l}\text { Absent }(71.2 \%) \text {; present } \\
(28.8 \%)\end{array}$ & $\begin{array}{l}\text { Absent }(69.5 \%) \text {; present } \\
(30.5 \%)\end{array}$ & $\begin{array}{l}\text { Low }(26.9-51.3 \%) \text {; high }(48.7- \\
73.1 \%)\end{array}$ \\
\hline
\end{tabular}

CPUE for small-scale operators (up to four people on board, covering $67.8 \%$ of survey respondents) was $52.1 \%$. When fishers' perceived habitat condition had improved and fish abundance was higher, the probability of CPUE being low decreased to $41.2 \%$ (Table 3). The probability of a low CPUE was further reduced to $28.3 \%$ when sighting of outsiders fishing in the respondents' territorial water was absent in addition to the improved habitat and fish abundance trend. When fishers perceived Sasi laut to be strong, the probability of CPUE being low decreased to $34.3 \%$, suggesting that Sasi laut alone could have a large impact on maintaining the CPUE level. Modernization of fishing gear also reduced the probability of a low CPUE by $5.2 \%$ to $46.9 \%$ (Table 3 ). These findings generally applied to all size of operators.

One of the key social objectives of customary tenure systems and traditional comanagement is to reduce the number of conflicts (FAO 1999), and examples have been reported within Indonesia (Campbell et al. 2012, Cinner et al. 2012a). The base case suggested that the probability of a fisher being involved in a conflict with other fishers in the same village (intravillage conflicts) was $30.6 \%$. Having a bad relationship with village leaders increased the probability of intravillage conflicts by almost $20 \%$ to $50.3 \%$, while having a bad relationship with fishery officers had a less severe impact, with only a $5 \%$ increase in the probability of intravillage conflicts. Tourism development also had a large impact on the presence of intravillage conflicts $(50.2 \%$ probability) when fishers perceived they were highly affected by tourism. The probability of intravillage conflicts was lower (26.4\%) when sighting of outsiders fishing in the respondents' territorial water was absent, compared to when it was present $(35.2 \%)$. In contrast, the probability of intervillage conflicts was slightly higher $(33.6 \%)$ when sighting of outsiders was absent, compared to when it was present $(26.5 \%)$ Similarly, lower perceived catch trends and lower fish stock abundance both reduced the probability of intravillage conflicts slightly (by $4.3 \%$ and $4.7 \%$, respectively) from the base case $(30.6 \%)$, while the 
Fig. 2. Bayesian belief network model showing the interrelationships of factors influencing fishing activities and resource management under a Sasi regime in the Kei Islands. See Table 2 for the definitions of the variables (CMT: customary marine tenure).

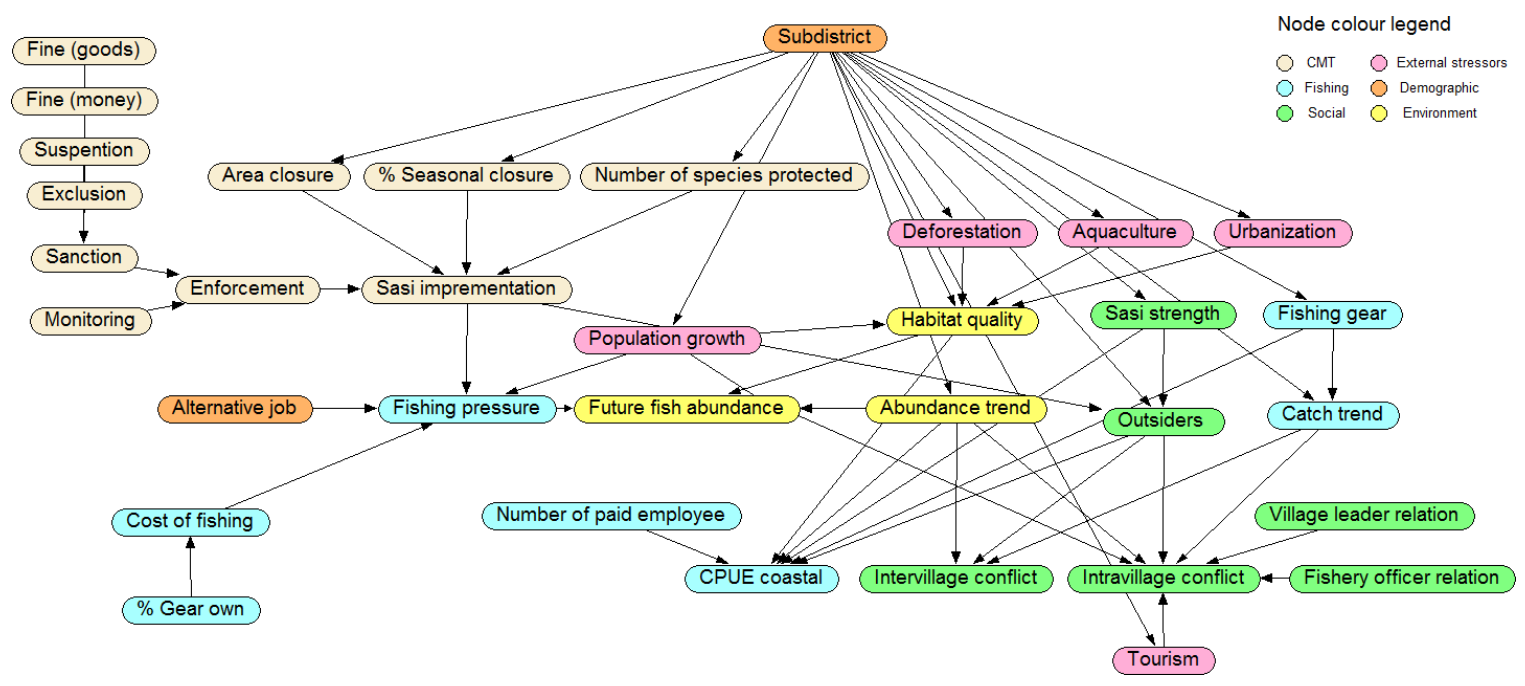

probability of intervillage conflict (conflicts with other villagers) increased from $30.1 \%$ to $40.3 \%$ with lower catch trend, and from $30.1 \%$ to $33.0 \%$ with lower fish abundance trend. When both catch and abundance trends were worse, the magnitude of the impact on the presence of conflict was much larger, with $29.2 \%$ reduction in intravillage conflict, and $12.6 \%$ increase in intervillage conflict.

Drawing on existing literature, we assumed that the states of future fish abundance, a key environmental objective of CMT, depended on the current fish abundance trend, habitat quality, and fishing pressure, which can be affected by the cost of fishing, availability of alternative employment, population growth, and implementation of CMT. The household survey results suggested that most respondents acknowledged the existence of Sasi rules, with $86.3 \%$ acknowledging the existence of temporal sea area closure, seasonal closure of approximately 1 month (on average), and protection of at least one species (in terms of harvest restrictions). Despite the high level of acknowledgement of Sasi rule existence, $92.3 \%$ of respondents felt that Sasi has weakened or totally disappeared in their village (Table 2). This gap is likely due to weak enforcement of Sasi regulations, as indicated by the low levels of sanctions (less than 6.4\% adopted any sanctions), high incidence of outsiders fishing in the respondents' territorial waters $(47.4 \%)$, and lack of vessel monitoring or patrolling to detect violation of Sasi. Adhuri (2013) also suggested that there are, in general, not enough speedboats and personnel to carry out patrols in the region. Our model suggests that strong enforcement through the introduction of a monitoring program to patrol the sea, and strong Sasi implementation in terms of a combination of customary area closures, seasonal closures, and species protection may reduce the probability of fishing pressure being high from approximately $47-52 \%$ to $30-33 \%$. This would be further reduced when population growth is lower $(21.3-25.7 \%)$ and alternative jobs are present (13.3-17.7\%). These factors together contribute to lower fishing pressure, which reduces the probability of future fish abundance being low from between $48.5 \%$ and $62.7 \%$ (base case) to between $26.9 \%$ and $51.3 \%$ (Table
3). A stronger Sasi implementation also means a better chance of achieving both the social and economic objectives, as a higher probability of increasing CPUE and lower conflicts can be expected through reduced incidence of outsiders fishing in the respondents' territorial waters.

\section{Sensitivity analyses}

The results of sensitivity analyses (Table 4) showed that for CPUE, the number of paid employee, modernization of fishing gear, and perceived habitat quality were the top three most influential factors in both subdistricts. The influence of Sasi strength and presence of outsiders fishing in the respondents' territorial water was ranked $4^{\text {th }}$ and $5^{\text {th }}$ in Dullah Utara, while perceived fish abundance and Sasi strength took the $4^{\text {th }}$ and $5^{\text {th }}$ place in Kei Kecil. External stressors, such as deforestation, urbanization, population growth, and aquaculture development all affect perceived habitat condition; hence, there are indirect impacts on CPUE, but their influence in terms of variance reduction was minimal (ranked $8^{\text {th }}-12^{\text {th }}$ ).

Factors most influential to intervillage conflicts were perceived catch trend (whether catch is increasing/decreasing or unchanged), sighting of outsiders fishing in the respondents' territorial waters, perceived fish abundance, modernization of fishing gear, and presence of intravillage conflicts in both subdistricts, although their ranks were slightly different in each subdistrict. Tourism, perceived fish abundance trend, catch trend, and sighting of outsiders were influential in terms of intravillage conflicts in both subdistricts. The influence of relationships with village leaders affected the probability of intravillage conflicts more in Dullah Utara, while the relationships with fishery officers affected it more in Kei Kecil.

In both subdistricts, fishing pressure was by far the most influential to the probability of future fish abundance, followed by perceived habitat quality, perceived current fish abundance trend, availability of alternative jobs, and Sasi implementation of 
Table 4. Sensitivity analysis results of factors affecting catch per unit effort (CPUE), conflicts, and future fish stock abundance. Only the factors with the five highest scores are shown.

\begin{tabular}{|c|c|c|c|}
\hline \multicolumn{2}{|c|}{ Dullah Utara } & \multicolumn{2}{|c|}{ Kei Kecil } \\
\hline \multicolumn{4}{|l|}{ Sensitivity of CPUE coastal } \\
\hline Factor & Variance reduction & Factor & Variance reduction \\
\hline Number of paid employees & 910.6 & Number of paid employees & 1417.0 \\
\hline Fishing gear & 521.3 & Fishing gear & 164.5 \\
\hline Habitat quality & 283.4 & Habitat quality & 123.4 \\
\hline Sasi strength & 149.3 & Abundance trend & 100.7 \\
\hline Outsiders & 51.4 & Sasi strength & 94.6 \\
\hline \multicolumn{4}{|l|}{ Sensitivity of intervillage conflicts } \\
\hline Factor & Entropy reduction & Factor & Entropy reduction \\
\hline Catch trend & 0.01995 & Catch trend & 0.02666 \\
\hline Outsiders & 0.00293 & Abundance trend & 0.00228 \\
\hline Fishing gear & 0.00088 & Outsiders & 0.00169 \\
\hline Abundance trend & 0.00031 & Intravillage conflict & 0.00078 \\
\hline Intravillage conflict & 0.00013 & Fishing gear & 0.00010 \\
\hline \multicolumn{4}{|l|}{ Sensitivity of intravillage conflicts } \\
\hline Factor & Entropy reduction & Factor & Entropy reduction \\
\hline Tourism & 0.00467 & Abundance trend & 0.01098 \\
\hline Abundance trend & 0.00463 & Tourism & 0.00868 \\
\hline Catch trend & 0.00210 & Fishery officer relation & 0.00728 \\
\hline Outsiders & 0.00149 & Catch trend & 0.00605 \\
\hline Village leader relation & 0.00098 & Outsiders & 0.00583 \\
\hline \multicolumn{4}{|l|}{ Sensitivity of future fish stock abundance } \\
\hline Factor & Entropy reduction & Factor & Entropy reduction \\
\hline Fishing pressure & 0.14797 & Fishing pressure & 0.14082 \\
\hline Habitat quality & 0.04283 & Habitat quality & 0.04238 \\
\hline Alternative job & 0.02417 & Alternative job & 0.02200 \\
\hline Abundance trend & 0.01255 & Abundance trend & 0.01269 \\
\hline Sasi implementation & 0.01044 & Sasi implementation & 0.01042 \\
\hline
\end{tabular}

management rules. This suggests that a combination of measures to reduce fishing pressure may be effective in achieving higher future fish abundance. Other lesser but important factors (ranked $\left.6^{\text {th }}-10^{\text {th }}\right)$ to future fish abundance were population growth, cost of fishing, CPUE, enforcement, and sea area closure.

Perceived fish abundance trend was listed as among the most important (top five) factors for all three indicators. This indicates that local knowledge about current fish abundance is a key driver of fishing activities that affect the successful outcome of achieving all social, economic, and environment objectives. Presence of outsiders fishing in the respondents' territorial water was another key driver that affected both CPUE and conflicts directly, and future fish abundance indirectly, since the frequency of sighting outsiders was linked to Sasi implementation.

\section{DISCUSSION}

It is well established that there are complex relationships, interactions, and feedbacks between factors that influence fishing activities (Gutierrez et al. 2011, Cinner et al. 2012b), particularly in coastal communities where customary management applies to local waters. The customary governance approaches to natural resources management, including in the marine environment, have many benefits (e.g., Ostrom 1990). However, many of the traditional customary tenure systems have either collapsed or are in danger of collapse (Evans et al. 1997, Thorburn 2000, 2001). Nongovernmental organizations, international donor communities, and national agencies are looking into reintroducing communitybased marine managed areas, but the functioning of customary marine tenure must be better understood if they are to be effectively incorporated into modern fishery management.

Understanding exactly how the social, economic, and environmental outcomes of customary governance systems are influenced by different human and natural drivers is key to continued, and potentially improved, customary management. A first step to either reinstating or reinvigorating customary management of marine resources is to understand the relationships between factors that influence fishing activities in coastal communities and how these factors affect the economic, social, and environmental outcomes of customary governance systems. The Kei Islands in Indonesia have long-established tenure systems where coastal resources have been communally owned and managed by traditional laws (Sasi) governing natural resources (Thorburn 2001), with subtle variations in the rules between villages. The Kei Islands are used as a case study community to investigate the factors that influence fishing behavior and Sasi outcomes. To our knowledge, this is the first 
study in which a Bayesian belief network has been applied to explore complex variable interactions and social, environmental, and economic outcomes in a customary marine tenure system.

Our results show that the cumulative impacts of multiple factors on key social, economic, and environmental outcomes can be much larger than the impact from a single source. For instance, the probability of a low CPUE for small-scale operators can be reduced much more when combining improved habitat quality, upward stock abundance trend, and absence of the sighting of outsiders fishing in their water (from $52 \%$ to $28 \%$ ) rather than only improving habitat quality (from $52 \%$ to $41 \%$ ). This implies that management or policy intervention could be more effective when addressing multiple factors simultaneously.

The local community's perception of the upward or downward trend of fish abundance is a key factor influencing social, economic, and environmental outcomes of Kei's CMT. Perceptions are distinct from actual observed trends and might in fact be at odds with trends. For instance, if local communities are mis- or under- informed, they might believe fish abundance is declining, where scientific measurements or monitoring might indicate it is increasing (or the reverse). Previous studies in Fiji and the Solomon Islands suggest that indigenous ecological knowledge about the health of coral reels and fish stocks is not always supported by quantitative studies (Aswani and Hamilton 2004, Albert et al. 2013). In the absence of a fishery-independent monitoring program, it remains unclear whether local knowledge about fish abundance in Kei is consistent with the actual trend. However, having adequate knowledge by itself, without concurrently having sufficient fish abundance, may not be enough to meet the three objectives. Nevertheless, it is important that government seeks to work in partnership with local communities and to combine the strengths of indigenous ecological knowledge and scientific information, since adequate local knowledge about current fish abundance may play a key role in successfully achieving social, economic, and environment outcomes in a CMT.

Perceptions of local people with respect to Sasi strength and catch trends were also important in meeting economic and social objectives, respectively. Perceptions can be changed, for instance, by improving the visibility of vessels monitoring and patrolling an area, which can in turn change the perception of Sasi strength and thus improve social outcomes for this CMT. Our results suggest that strengthening of Sasi alone has the most prominent impact on improving the economic (CPUE) indicator, which supports Ruttan's (1998) argument that the intention behind the marine Sasi in Kei Besar Island is to maximize economic benefits rather than conservation.

Our results also suggest that sighting outsider presence and outsider fishing activity in territorial water is another key driver that directly affects economic and social outcomes, and indirectly affects environmental outcomes. The frequency of which outsiders are sighted in territorial waters is strongly linked to the perceived weakness or strength of Sasi implementation, although results were found to be in opposing directions for intravillage (negatively affected by stronger Sasi) and intervillage conflicts (positively affected). The absence of outsiders can mean that stronger exclusive user rights are in place (i.e., due to stronger Sasi), which can in turn increase intervillage conflicts, while at the same time reducing intravillage conflicts. This can create complexity, as one of the key social objectives of customary tenure systems and traditional comanagement is to reduce conflicts, and lower levels of conflict suggest greater social capital, which is considered integral to successful common-pool fishery management.

Similarly, both lower perceived catch and fish abundance trends reduced the probability of intravillage conflicts slightly where the probability of intervillage conflicts increased (Table 3). In other words, worsening environmental conditions have different effects on the occurrence of intravillage and intervillage conflicts. This may be because fishers in the same village cooperate to overcome unfavorable fishing conditions, while such conditions may provide incentives for fishers to operate in other villages' territorial waters; hence, increased intervillage conflicts. These interrelationships strongly illustrate the close connection between ecological and social outcomes, and the importance of considering socialecological systems as a whole.

Our results (Table 3) suggest that tourism development has a large impact on the presence of intravillage conflicts. This may be due to the nonextractive nature of tourism being in conflict with the extractive nature of fishing, and the two are not perceived to be complimentary activities. Increased tourism therefore means more conflict between those who fish and those involved in the tourism sector. This is interesting in that tourism is often presented as the "economic savior" of tropical reef systems (and small islands in the Pacific and elsewhere), but it may in fact create conflict within the village and thus potentially undermine the comanagement of the area (or the Sasi). In addition, the intravillage conflict over tourism development could also result in additional intervillage conflict. This perceived conflict between simultaneous tourism and fishing activities was apparent in both of the Kei Island study regions (Table 4), which suggests that this conflict may also bear out at a broad regional scale.

Comanagement approaches and traditional customary tenure systems are highly vulnerable to discontinuities and asymmetries developing between the social, economic, and ecological system (Ruddle 1993, Hviding 1998). The potential for disassociation between the social and ecological domains in the Sasi comanagement system suggests that equal attention should be paid to monitoring both social acceptance and environmental sustainability. If the social perception of Sasi effectiveness is slowly being eroded, it may be difficult to correct this retrospectively or to resurrect the Sasi should it cease to exist locally. This may be particularly true for villages that are internally socially challenged. The BBN model suggests that intravillage conflict explains intervillage conflict (but not vice versa). Villages that are internally socially challenged are also more likely to be externally socially challenged. So if an internally strong community can be maintained, it is more likely that harmonious resource sharing will occur with other villages.

Interviews undertaken as part of this project revealed that there was a high level of local knowledge of Sasi and the existing governance rules. However, this intimate local knowledge of Sasi did not translate into general acceptance of the Sasi system in the sense that a high number of people believed the rules were unsuccessful and often not observed by marine resource users. This may at first glance seem problematic, but the high level of 
knowledge and at the same time the large number of disaffected people may in fact provide an opportunity for improving the functioning of Sasi in the future. A recent study conducted in Ache Province of Indonesia suggests that people who had positive views of their customary management systems were generally more wealthy and had higher fortnightly expenditure (Setiawan et al. 2012). Greater wealth and lower poverty can play a critical role in the perception of CMT (Cinner and Pollnac 2004), and our study will benefit from the inclusion of general household expenditure (a proxy for household income) in the $\mathrm{BBN}$ framework when such data become available. Strengthening vessel monitoring or patrolling to detect offenses and weak sanctions also seems to provide a way to improve the Sasi and change community perceptions of its success. Our interviews with villagers, as well as Adhuri (2013), suggest that sometimes Sasi itself causes local conflicts when Sasi is implemented improperly (different from the original meaning defined in the Larwul Ngabal customary law). As such misuse of Sasi can create uneven distribution of marine resources and distrust between village leaders and villagers, we suggest that future studies consider perceived objectives of Sasi and how these perceptions affect resource management outcomes. As mentioned in the preceding paragraph, problems need to be addressed before the point at which the Sasi problems and weaknesses become irreversible. Facilitation of change by means of increasing (self or externally driven) monitoring and enforcement while maintaining ownership may be a good starting point. Monitoring and enforcement can be improved by increasing the presence of local village patrollers or enforcement agencies (Takahashi and van Duijn 2012) but also, for instance, by increasing education or changing the fisher's decision framework. Decision frameworks can be changed, for instance, by providing opportunities for anonymous incidence reporting, which has proven to change behavior and perceptions in some other locations (Aaron et al. 2000).

\section{CONCLUSION}

The core of a successful customary management system lies in the achievement of different environmental and socioeconomic objectives. For a coastal community with a CMT system to achieve its different objectives, the drivers that influence fishing behavior have to be well understood. A BBN model based on empirical data can be used to represent different factors that drive fishing activity and to assess the influence and impact of changing social, economic, and environmental conditions on meeting the community's CMT objectives.

Bayesian belief network models are particularly useful in highlighting current information and knowledge gaps that are important for decision-makers, but as additional or more accurate resource user or community information becomes available, models can be further developed and expanded. Impacts following changes in fishery management, while accounting for uncertainties regarding costs and benefits of management decisions (e.g., effectiveness of introducing a monitoring program), can be trailed using these flexible models. Extended models are useful as decision support tools for resource management, as interactions between variables and the relative influence of variables on final management outcomes can be easily explored.
In this study, we found that the current lack of empirical information available to quantify the level of fishing pressure, which is a key variable in its impact on future stock abundance, needs immediate attention to ensure that CMT objectives will be met in the foreseeable future. Aside from accurate fishing pressure information, the continued existence and potential future creation of CMTs to manage marine resources in coastal communities that depend on these resources for livelihoods and food security relies on government programs that carefully consider local cultural values. Ensuring congruence with local values and perceptions of CMT effectiveness, for instance through monitoring and patrolling, will likely determine the longevity of these management systems. Strong local support for the CMT is a key driver of lasting success. Aside from influencing factors that directly affect cultural and social perceptions of the CMT, governments also have to positively influence indirect factors such as job creation and reducing local poverty.

Responses to this article can be read online at: http://www.ecologyandsociety.org/issues/responses. $\mathrm{php} / 8285$

\section{LITERATURE CITED}

Aaron, H., S. Jaffry, O. Thébaud, and E. Bennett. 2000. Normative and social influences affecting compliance with fishery regulations. Land Economics 76(3):448-461. http://dx.doi. org/10.2307/3147040

Adhuri, D. S. 2013. Selling the sea, fishing for power: a study of conflict over marine tenure in Kei Islands, eastern Indonesia. Australian National University E Press, Canberra, Australia.

Albert, S., M. Love, and T. D. Brewer. 2013. Contrasts in social and ecological assessments of coral reef health in Melanesia. Pacific Science 67(3):409-424. http://dx.doi.org/10.2984/67.3.8

Aswani, S., G. G. Gurney, S. Mulville, J. Matera, and M. Gurven. 2013. Insights from experimental economics on local cooperation in a small-scale fishery management system. Global Environmental Change 23(6):1402-1409. http://dx.doi.org/10.1016/ j.gloenvcha.2013.08.003

Aswani, S., and R. J. Hamilton. 2004. Integrating indigenous ecological knowledge and customary sea tenure with marine and social science for conservation of bumphead parrotfish (Bolbometopon muricatum) in the Roviana Lagoon, Solomon Islands. Environmental Conservation 31(01):69-83. http://dx.doi. org/10.1017/s037689290400116x

Badan Pusat Statistik. 2014a. Maluku tenggara in figures (p. 344). Southeast Maluku Regency (badan pusat statistik kabupaten maluku tenggara). Central Board of Statistic.

Badan Pusat Statistik. 2014b. Tual in figures (p. 320). Southeast Maluku Regency (badan pusat statistik kabupaten maluku tenggara). Central Board of Statistic.

Campbell, S. J., J. E. Cinner, R. L. Ardiwijaya, S. Pardede, T. Kartawijaya, A. Mukmunin, Y. Herdiana, A. S. Hoey, M. S. Pratchett, and A. H. Baird. 2012. Avoiding conflicts and 
protecting coral reefs: customary management benefits marine habitats and fish biomass. Oryx 46(04):486-494. http://dx.doi. org/10.1017/s0030605312000348

Cinner, J. 2005. Socioeconomic factors influencing customary marine tenure in the Indo-Pacific. Ecology and Society 10(1):36.

Cinner, J. E., X. Basurto, P. Fidelman, J. Kuange, R. Lahari, and A. Mukminin. 2012a. Institutional designs of customary fisheries management arrangements in Indonesia, Papua New Guinea, and Mexico. Marine Policy 36(1):278-285. http://dx.doi. org/10.1016/j.marpol.2011.06.005

Cinner, J. E., T. R. McClanahan, M. A. MacNeil, N. A. J. Graham, T. M. Daw, A. Mukminin, D. A. Feary, A. L. Rabearisoa, A. Wamukota, N. Jiddawi, S. J. Campbell, A. H. Baird, F. A. Januchowski-Hartley, S. Hamed, R. Lahari, T. Morove, and J. Kuange. 2012b. Comanagement of coral reef social-ecological systems. Proceedings of the National Academy of Sciences 109 (14):5219-5222. http://dx.doi.org/10.1073/pnas.1121215109

Cinner, J. E., and R. B. Pollnac. 2004. Poverty, perceptions and planning: why socioeconomics matter in the management of Mexican reefs. Ocean \& Coastal Management 47(9-10):479-493. http://dx.doi.org/10.1016/j.ocecoaman.2004.09.002

Cooke, A. J., N. V. C. Polunin, and K. Moce. 2000. Comparative assessment of stakeholder management in traditional Fijian fishing-grounds. Environmental Conservation 27(03):291-299. http://dx.doi.org/10.1017/s0376892900000333

Cox, M., G. Arnold, and S. V. Tomás. 2010. A review of design principles for community-based natural resource management. Ecology and Society 15(4):38.

Evans, S. M., M. E. Gill, A. S. W. Retraubun, J. Abrahamz, and J. Dangeubun. 1997. Traditional management practices and the conservation of the gastropod (Trochus nilitocus) and fish stocks in the Maluku Province (eastern Indonesia). Fisheries Research 31(1-2):83-91. http://dx.doi.org/10.1016/s0165-7836(97)00011-8

Food and Agriculture Organization of the United Nations (FAO). 1999. Use of property rights in fisheries management. FAO Fisheries Technical Paper 404/1. FAO, Rome, Italy.

Gutierrez, N. L., R. Hilborn, and O. Defeo. 2011. Leadership, social capital and incentives promote successful fisheries. Nature 470(7334):386-389. http://dx.doi.org/10.1038/nature09689

Haapasaari, P., and T. P. Karjalainen. 2010. Formalizing expert knowledge to compare alternative management plans: sociological perspective to the future management of Baltic salmon stocks. Marine Policy 34(3):477-486. http://dx.doi. org/10.1016/j.marpol.2009.10.002

Hviding, E. 1998. Contextual flexibility: present status and future of customary marine tenure in Solomon Islands. Ocean \& Coastal Management 40(2-3):253-269. http://dx.doi.org/10.1016/S0964-5691 (98)00042-8

Korb, K. B., and A. E. Nicholson. 2011. Bayesian artificial intelligence. Chapman \& Hall/CRC, London, UK. http://dx.doi. org/10.1201/9780203491294

Kuikka, S., M. Hildén, H. Gislason, S. Hansson, H. Sparholt, O. Varis, S. Kuikka, M. Hildén, H. Gislason, S. Hansson, H.
Sparholt, and O. Varis. 1999. Modeling environmentally driven uncertainties in Baltic cod (Gadus morhua) by Bayesian influence diagrams. Canadian Journal of Fisheries and Aquatic Sciences 56 (4):629-641. http://dx.doi.org/10.1139/f98-206

Levontin, P., S. Kulmala, P. Haapasaari, and S. Kuikka. 2011. Integration of biological, economic, and sociological knowledge by Bayesian belief networks: the interdisciplinary evaluation of potential management plans for Baltic salmon. ICES Journal of Marine Science: Journal du Conseil 68(3):632-638. http://dx.doi. org/10.1093/icesjms/fsr004

Liese, C., M. D. Smith, and R. A. Kramer. 2007. Open access in a spatially delineated artisanal fishery: the case of Minahasa, Indonesia. Environment and Development Economics 12(01):123143. http://dx.doi.org/10.1017/s1355770x06003421

Little, L. R., S. Kuikka, A. E. Punt, F. Pantus, C. R. Davies, and B. D. Mapstone. 2004. Information flow among fishing vessels modelled using a Bayesian network. Environmental Modelling \& Software 19(1):27-34. http://dx.doi.org/10.1016/s1364-8152(03) $\underline{00100-2}$

Marcot, B. G., J. D. Steventon, G. D. Sutherland, and R. K. McCann. 2006. Guidelines for developing and updating Bayesian belief networks applied to ecological modeling and conservation. Canadian Journal of Forest Research 36(12):3063-3074. http://dx. doi.org/10.1139/x06-135

Mosse, J. W., J. M. S. Tetelepta, and F. X. V. R. Letsoin. 2012. Hawear di kepulauan kei (hawear in Kei Islands). Ambon.

Nikijuluw, V. P. H. 1994. Indigenous fisheries resource management in the Maluku Islands. Indigenous Knowledge and Development Monitor 2(2):6-8.

Novaczek, I., H. T. Harkes, J. Sopacua, and M. D. D. Tatuhey. 2001. An institutional analysis of Sasi laut in Maluku, Indonesia. The WorldFish Center, Penang, Malaysia.

Ostrom, E. 1990. Governing the commons: the evolution of institutions for collective action. Cambridge University Press, Cambridge, UK and New York, U.S.A. http://dx.doi.org/10.1017/ CBO9780511807763

Pollnac, R., P. Christie, J. E. Cinner, T. Dalton, T. M. Daw, G. E. Forrester, N. A. J. Graham, and T. R. McClanahan. 2010. Marine reserves as linked social-ecological systems. Proceedings of the National Academy of Sciences 107(43):18262-18265. http://dx. doi.org/10.1073/pnas.0908266107

Ruddle, K. 1993. External forces and change in traditional community-based pshery management systems in the Pacific island region. Maritime Anthropological Studies 6(1-2):1-37.

Ruddle, K. 1998. The context of policy design for existing community-based fisheries management systems in the Pacific Islands. Ocean \& Coastal Management 40(2-3):105-126. http:// dx.doi.org/10.1016/s0964-5691(98)00040-4

Ruttan, L. M. 1998. Closing the commons: cooperation for gain or restraint? Human Ecology 26(1):43-66. http://dx.doi. org/10.1023/A:1018744816814

Setiawan, A., J. E. Cinner, S. G. Sutton, and A. Mukminin. 2012. The perceived impact of customary marine resource management 
on household and community welfare in northern Sumatra, Indonesia. Coastal Management 40(3):239-249. http://dx.doi. org/10.1080/08920753.2012.677626

Southeast Maluku Regional Development Planning Agency. 2012. Southeast Maluku regency spatial plan 563. 2012-2032. Government of Southeast Maluku Regency, Langgur, Indonesia.

Takahashi, B., and A. P. van Duijn. 2012. Operationalizing fisheries co-management: lessons learned from lagoon fisheries co-management in Thua Thien Hue Province, Viet Nam. FAP Regional Office for Asia and the Pacific, Bangkok, Thailand.

Thorburn, C. 2001. The house that poison built: customary marine property rights and the live food fish trade in the Kei Islands, Southeast Maluku. Development and Change 32(1):151180. http://dx.doi.org/10.1111/1467-7660.00200

Thorburn, C. C. 2000. Changing customary marine resource management practice and institutions: the case of Sasi lola in the Kei Islands, Indonesia. World Development 28(8):1461-1479. http://dx.doi.org/10.1016/s0305-750x(00)00039-5

Ticehurst, J. L., L. T. H. Newham, D. Rissik, R. A. Letcher, and A. J. Jakeman. 2007. A Bayesian network approach for assessing the sustainability of coastal lakes in New South Wales, Australia. Environmental Modelling \& Software 22(8):1129-1139. http://dx. doi.org/10.1016/j.envsoft.2006.03.003

van Putten, I., A. Lalancette, P. Bayliss, D. Dennis, T. Hutton, A. Norman-López, S. Pascoe, E. Plagányi, and T. Skewes. 2013. A Bayesian model of factors influencing indigenous participation in the Torres Strait tropical rocklobster fishery. Marine Policy 37:96-105. http://dx.doi.org/10.1016/j.marpol.2012.04.001

Varis, O., and S. Kuikka. 1997. Joint use of multiple environmental assessment models by a Bayesian meta-model: the Baltic salmon case. Ecological Modelling 102(2-3):341-351. http://dx.doi.org/10.1016/s0304-3800(97)00068-9

Viswanathan, K. K., I. H. Omar, Y. Jeon, J. Kirkley, D. Squires, and I. Susilowati. 2001. Fishing skill in developing country fisheries: the kedah, Malaysia trawl fishery. Marine Resource Economics 16(4):293-314. http://dx.doi.org/10.1086/mre.16.4.42629339

Yu, J., V. A. Smith, P. P. Wang, A. J. Hartemink, and E. D. Jarvis. 2004. Advances to Bayesian network inference for generating causal networks from observational biological data. Bioinformatics 20(18):3594-3603. http://dx.doi.org/10.1093/bioinformatics/bth448 